\title{
The Role of Internal Control Unit as the Strategic Step to Achieve Good University Governance in the University with Status of Public-Service-Institution
}

\author{
Muhammad Ridha Habibi $Z^{1^{*}}$, Sofyan Hidayat ${ }^{2}$ \\ ${ }^{1,2}$ Department of Accounting, Faculty of Economics, Universitas Negeri Medan \\ *mridhahabibi@unimed.ac.id
}

\begin{abstract}
The existence of higher education institutions very essential for the nation. It is needed to implement the concept of governance that is considered ideal is known as Good University Governance (GUG). According to Wijatno (2009:370), there are five principles of Good University Governance (GUG) namely, (1) transparency, (2) accountability, (3) responsibility, (4) independence, and (5) justice. Good University Governance (GUG) emerged as a very fundamental value system to improve the value of higher education especially with the change in the status of higher education into a PKBLU pattern. This study aims to determine the effect of the role of the internal control unit on good university governance. The study used primary data in the form of a questionnaire that will be sent to the Office of the Internal Control Unit / Internal Audit Office of university under Inspectorate General of the Ministry of Education and Culture Region II. The data analysis method used the quantitative analysis. The analytical tool used descriptive analysis and inferential statistical analysis using simple regression. The result of the F statistical test was 64,214 with a significance value of 0,000 . It indicates that the Internal Control Unit affects Good University Governance.
\end{abstract}

Keywords: Good University Governance, Internal Control Unit

\section{Introduction}

The university has a big role in supporting development agenda. For this reason, Good University Governance (GUG) is known as the ideal concept of governance which can support the institution to achieve the goal. According to Wijatno [1] there are five principles of Good University Governance (GUG) namely, (1) transparency, (2) accountability, (3) responsibility, (4) independence, and (5) justice. The majority universities in this study are the units under the Ministry of Education and Culture. The quality of the Ministry of Education and Culture's performance can be seen from the audit opinion given by the Financial Audit Body (shortly BPK, in Indonesian). Overall, it depends on the performance of each units under the aegis.

The Ministry of Education and Culture received Disclaimer of opinion for 2010 financial statement. It indicates a decline in accountability compared to 2009 which is qualified opinion. It happened because of the low quality performance of the units under the ministry included universities. This fact shows that the management of university in Indonesia is not optimal. Good University Governance (GUG) emerged as a very fundamental value system to improve the value of higher education especially with the change in the status of university into a Public-Service-Institution (PK-BLU in Indonesian) pattern. 


\section{Research Method}

\section{Data collection technique}

The questionnaire in this study was used to obtain data from the PK-BLU Universityunder the Inspector General of the Ministry of Research and Technology Region II. Data collection is done by sending questionnaires by post addressed to BLU institution. Then to get the feedback, in the envelope was attached a reply envelope that has been equipped with stamps and the destination address.

Data analysis uses regression analysis techniques. To test the hypothesis with regression analysis, the assumption test is done first, the normality test, the multicollinearity test, homogeneity and reliability. After testing the requirements and fulfilling the criteria, a hypothesis test can be performed

\section{Regression Analysis}

The hypothesis in this study was tested using simple linear regression analysis. This regression model aims to examine the effect of the independent variable, namely the Role of the Internal Control Unit on the dependent variable, namely Good University Governance in the State University of Medan during BLU status. The simple linear regression formula used is as follows:

$$
\mathbf{Y}=\mathbf{a}+\mathbf{b}_{1} \mathbf{X}_{1}+\mathbf{e}
$$

Note:

$\mathrm{Y}=$ Good University Governance

$\mathrm{A}=$ Constant

$\mathrm{b}_{1}=$ Regression coefficient

$\mathrm{X}=$ Role of the Internal Control Unit

$\mathrm{e}=$ Epsilon

\section{Hypothesis test}

In this test, the coefficient of determination $\left(\mathrm{R}^{2}\right)$ will be calculated to explain the dependent variable. The F-statistic test is used to test the significance of a relation or regression which shows whether all independent or independent variables have an influence on the dependent variable. Provisions regarding the rejection and acceptance of a hypothesis are as follows:

1) If the significance $>0.05$, the hypothesis is rejected (does not have a significant effect).

2) If the significance $<0.05$, the hypothesis is accepted (has a significant influence).

\section{Results and Discussion}

The respondents are classified into characteristics below:

Table 1. Age of Respondent

\begin{tabular}{lll}
\hline Description & Number & Percentage \\
\hline$<25$ year & 2 & $6 \%$ \\
$25-40$ year & 23 & $70 \%$ \\
$>40$ year & 8 & $24 \%$ \\
\hline Total & 33 & $100 \%$ \\
\hline
\end{tabular}


The table shows that the respondents (23 people or $70 \%$ ) ages $25-40$ years, respondents are $>40$ years age as many as 8 people or $24 \%$, and respondents aged $<25$ years are 2 people or $2 \%$.

Table 2. Education

\begin{tabular}{lll}
\hline Description & Number & Percentage \\
\hline Diploma & 0 & $0 \%$ \\
Bachelor & 17 & $52 \%$ \\
Master & 14 & $42 \%$ \\
Doctoral & 2 & $6 \%$ \\
\hline Total & 33 & $100 \%$ \\
\hline
\end{tabular}

The table shows that the majority of respondents (17 people or $52 \%$ ) have bachelor degree. For respondents with a Master's degree, there were 14 people or $42 \%$. For respondents with a doctoral degree, there are 2 people or $6 \%$.

Table 3. Department of Respondent

\begin{tabular}{lll}
\hline Description & Number & Percentage \\
\hline Accounting & 20 & $61 \%$ \\
Management & 1 & $3 \%$ \\
Economics & 2 & $6 \%$ \\
Law & 2 & $6 \%$ \\
Engineering & 6 & $18 \%$ \\
Others & 2 & $6 \%$ \\
\hline Total & 33 & $100 \%$ \\
\hline
\end{tabular}

The last major is accounting dominate as many as 20 people or $61 \%$, for respondents whose last major is management as many as 1 person or $3 \%$, for respondents whose last major is economics as many as 2 people or $6 \%$, for respondents whose last major is law namely as many as 2 people or $6 \%$, for respondents whose last major was engineering, as many as 6 people or $18 \%$, and respondents with other majors were as many as 2 people or $6 \%$.

Table 4. Length of Work

\begin{tabular}{lll}
\hline Description & Number & Percentage \\
\hline$<3$ year & 10 & $30 \%$ \\
3-5 year & 9 & $27 \%$ \\
$>5$ year & 14 & $43 \%$ \\
\hline Total & 33 & $100 \%$ \\
\hline
\end{tabular}

From the table above it can be seen that the respondents who worked less than 3 years were 10 people or $30 \%$, respondents who worked 3-5 years were 9 people or $27 \%$, and the rest who worked over 5 years were 14 people or $43 \%$.

Variables used in this study include competence (TKP), independence (TID), the role of internal auditors (TPA), and the effectiveness of the internal control system (TESP) will be tested while descriptive statistics as shown in table 5. 
Table 5. The Result of Statistical Descriptive Test Descriptive Statistics

\begin{tabular}{llllll}
\hline & $\mathrm{N}$ & Min. & Max. & Mean & Std.Deviation \\
\hline TOTAL_SPI & 33 & 62 & 110 & 91,42 & 9,011 \\
TOTAL_GUG & 33 & 60 & 94 & 81,67 & 7,326 \\
$\begin{array}{l}\text { Valid N } \\
\text { (listwise) }\end{array}$ & 33 & & & & \\
\hline
\end{tabular}

For SPI variable, the minimum answer of respondents is 62 , a maximum of 110 with an average total answer is 91.42 and a standard deviation of 9,011. While the GUG variable has a minimum answer of 60 and a maximum of 94 with an average answer of 81.67 and a standard deviation of 7.326. Based on the results of the descriptive statistical tests above, it can be concluded that the average respondent's answers to internal control unit variables and good university governance are agreed upon.

Table 6. The Validity of SPI items

\begin{tabular}{lccl}
\hline correlation & $\begin{array}{c}\text { value correlation } \\
\text { coefficient (r) }\end{array}$ & r table & Description \\
\hline Item 1 & 0,667 & 0,344 & Valid \\
Item 2 & 0,589 & 0,344 & Valid \\
Item 3 & 0,651 & 0,344 & Valid \\
Item 4 & 0,750 & 0,344 & Valid \\
Item 5 & 0,692 & 0,344 & Valid \\
Item 6 & 0,808 & 0,344 & Valid \\
Item 7 & 0,794 & 0,344 & Valid \\
Item 8 & 0,382 & 0,344 & Valid \\
Item 9 & 0,545 & 0,344 & Valid \\
Item 10 & 0,640 & 0,344 & Valid \\
Item 11 & 0,462 & 0,344 & Valid \\
Item 12 & 0,521 & 0,344 & Valid \\
Item 13 & 0,732 & 0,344 & Valid \\
Item 14 & 0,579 & 0,344 & Valid \\
Item 15 & 0,800 & 0,344 & Valid \\
item 16 & 0,707 & 0,344 & Valid \\
item 17 & 0,611 & 0,344 & Valid \\
item 18 & 0,515 & 0,344 & Valid \\
item 19 & 0,424 & 0,344 & Valid \\
item 20 & 0,408 & 0,344 & Valid \\
item 21 & 0,800 & 0,344 & Valid \\
item 22 & 0,707 & 0,344 & Valid \\
\hline
\end{tabular}

In this study, the number of samples (n) was 33 respondents and the magnitude of df was $33-2=31$, with $\mathrm{df}=31$ and alpha $=0.05$ and rtable $=0.344$ in the $\mathrm{r}$ table (person product moment). To see whether each indicator is valid or not, it can be seen from the output croanbach display alpha in the column correlated item- Total Correlation in both SPI and 
GUG. Then the value correlated item- Total Correlation compared with the results of the calculation of the value of rtable $=0.344$. If the value of rcount $>$ rtable then the item or question is declared valid (Ghozali, 2013). The results obtained from testing the validity of SPI are as follows:

Based on table 6, all of the question items SPI variable is declared valid because all values are greater than value $\mathrm{r}_{\text {tabel. }}$. The results obtained from testing the validity of GUGitems is as follows:

Table 7. The Validity of GUG items

\begin{tabular}{lccl}
\hline Correlation & $\begin{array}{c}\text { Value correlation } \\
\text { coefficient (r) }\end{array}$ & r table & Description \\
\hline Item 1 & 0,369 & 0,344 & Valid \\
Item 2 & 0,451 & 0,344 & Valid \\
Item 3 & 0,359 & 0,344 & Valid \\
Item 4 & 0,808 & 0,344 & Valid \\
Item 5 & 0,765 & 0,344 & Valid \\
Item 6 & 0,380 & 0,344 & Valid \\
Item 7 & 0,571 & 0,344 & Valid \\
Item 8 & 0,640 & 0,344 & Valid \\
Item 9 & 0,560 & 0,344 & Valid \\
Item 10 & 0,675 & 0,344 & Valid \\
Item 11 & 0,810 & 0,344 & Valid \\
Item 12 & 0,597 & 0,344 & Valid \\
Item 13 & 0,672 & 0,344 & Valid \\
Item 14 & 0,744 & 0,344 & Valid \\
Item 15 & 0,634 & 0,344 & Valid \\
item 16 & 0,708 & 0,344 & Valid \\
item 17 & 0,692 & 0,344 & Valid \\
item 18 & 0,738 & 0,344 & Valid \\
item 19 & 0,761 & 0,344 & Valid \\
\hline
\end{tabular}

Based on Table 7, all items of a variable GUG question is valid for the entire value greater than $r_{\text {tabel. }}$. The result of the reliability test is as follows:

Table 8. Reliability Statistics

\begin{tabular}{ll}
\hline Cronbach's Alpha & N of Items \\
\hline, 752 & 23 \\
\hline
\end{tabular}

In reliability testing the variable $S P I$ overall is 0.752 . Because the reliability value of SPI is $0.752>0.60$, this variable is reliable and suitable for further analysis. The results obtained from the GUG reliability test are as follows: 
Table 9. Reliability Statistics

\begin{tabular}{ll}
\hline Cronbach's Alpha & N of Items \\
\hline, 755 & 20 \\
\hline
\end{tabular}

In testing the reliability of the variable GUGoverall is 0.755 . Because the GUG reliability value is $0.755>0.60$, this variable is reliable and is suitable for use in the regression analysis.

Table10. One-Sample Kolmogorov-Smirnov Test

\begin{tabular}{lll}
\hline & & $\begin{array}{l}\text { Unstandardized } \\
\text { Residual }\end{array}$ \\
\hline $\mathrm{N}$ & Mean & 33 \\
Normal Parameters &, 0000000 \\
& Std. Deviation & 4,18006950 \\
Most Extreme Differences & Absolute &, 140 \\
& Positive &, 140 \\
& Negative &,- 099 \\
Kolmogorov-Smirnov Z & &, 802 \\
Asymp. Sig. (2-tailed) &, 541 \\
$\begin{array}{l}\text { a. Test distribution is Normal. } \\
\text { b. Calculated from data. }\end{array}$ & \\
\hline
\end{tabular}

According to Ghozali [2] if the Kolmogorov Smirnov test results value Asymp. Sig. (2tailed) is greater than 0.05 , then the data is normally distributed. The probability of the Kolmogorov Smirnov test results in Table 5.13 shows the Asymp value. Sig. (2-tailed) is greater than 0.05 which is 0.541 . It means that the variable data in this study has been normally distributed or meets the normality assumption.

The result of multicollinearity test shows that the tolerance value is above 0.1 and the VIF value is below 10 so that the regression model is free from multicollinearity.

Table11. Multicollinearity test

\begin{tabular}{|c|c|c|c|}
\hline \multicolumn{2}{|c|}{ Model } & \multicolumn{2}{|c|}{ Collinearity Statistics } \\
\hline \multirow[t]{2}{*}{1} & (Constant) & Tolerance & VIF \\
\hline & TOTAL_SPI & 1,000 & 1,000 \\
\hline
\end{tabular}

a. Dependent Variable: Abs_RES

Table 12. The Result of Heteroscebdasticity test Coefficients $^{\mathrm{a}}$

\begin{tabular}{|c|c|c|c|c|c|c|c|}
\hline \multirow[t]{2}{*}{ Model } & $\begin{array}{l}\text { Unstandardized } \\
\text { Coefficients }\end{array}$ & & $\begin{array}{l}\text { Standardized } \\
\text { Coefficients }\end{array}$ & $\mathrm{T}$ & Sig. & $\begin{array}{l}\text { Collinearity } \\
\text { Statistics }\end{array}$ & \\
\hline & $\mathrm{B}$ & Std. Error & Beta & & & Tolerance & VIF \\
\hline (Constant) & $-9,696 \mathrm{E}-15$ & 7,653 & &, 000 & 1,000 & & \\
\hline TOTAL_SPI &, 000 &, 083 &, 000 &, 000 & 1,000 & 1,000 & 1,000 \\
\hline
\end{tabular}

a. Dependent Variable: Abs_RES 
Based on table 12, it can be seen that the significance value of the SPI variable is 1.000 . Thus the significance value of variables $>0.05$, shows that it is free from heteroscedasticity.

Table 13. The Result of Determinant Coefficient Test $\left(\mathrm{R}^{2}\right)$ Model Summaryb

\begin{tabular}{|c|c|c|c|c|}
\hline Model & $\mathrm{R}$ & R Square & $\begin{array}{l}\text { Adjusted } \\
\text { Square }\end{array}$ & $\begin{array}{l}\text { R Std. Error of the } \\
\text { Estimate }\end{array}$ \\
\hline 1 & $821^{\mathrm{a}}$ & 674 &, 664 & 4,247 \\
\hline
\end{tabular}

a. Predictors: (Constant), TOTAL_SPI

b. Dependent Variable: TOTAL_GUG

Table 13 above shows the Adjusted $R$ Square value of 0.664 . It indicates that the SPI variable can explain $66.4 \%$ variation in the effectiveness variable of the internal control system. While the remaining $33.6 \%$ is explained by other variables outside the research model. According to Lestari (2013), the variables that can affect to achieve good governance are risk management, company or organizational policies and organizational information transparency.

Table 14. The Result of Simultaneous Test

\begin{tabular}{|c|c|c|c|c|c|c|}
\hline \multicolumn{2}{|c|}{ Model } & \multirow{2}{*}{$\begin{array}{c}\text { Sum of Squares } \\
1158,198\end{array}$} & \multirow{2}{*}{$\begin{array}{l}\text { Df } \\
1\end{array}$} & \multirow{2}{*}{$\begin{array}{c}\text { Mean Square } \\
1158,198\end{array}$} & \multirow{2}{*}{$\begin{array}{l}F \\
64,214\end{array}$} & \multirow{2}{*}{$\frac{\text { Sig. }}{, 000^{\mathrm{a}}}$} \\
\hline 1 & Regression & & & & & \\
\hline & Residual & 559,135 & 31 & 18,037 & & \\
\hline & Total & 1717,333 & 32 & & & \\
\hline
\end{tabular}

a. Predictors: (Constant), TOTAL SPI

b. Dependent Variable: TOTAL_GUG

$\mathrm{H}_{1}$ : The role of the internal control unit has a positive effect on good university governance in university with the status of BLU.

Table 14 above shows the $F$ value of 64.214 with a significance value of 0.000 . Because the significance probability is smaller than 0.05 , it can be concluded that $\mathrm{H}_{1}$ is accepted.It can be said that the Internal Control Unit effect on Good University Governance. The results of this study support the results of research conducted by Untari [3]. Internal auditors are needed to assess management's accountability and compliance with policies and regulations that apply to the interests of stakeholders. It also needs to be done in the management of university in order to produce economic, efficiency and effectiveness (3E). Therefore, the internal control unit is seen as having an important role in the effort to create a university that is capable of having good management (Good University Governance)[6]

Internal auditors or SPI are considered important in realizing the creation of university that is able to carry out its role and able to prevent fraud occurring in university management so that it can carry out its knowledge transfer functions to the maximum and be accountable in its financial management and accountability and in compliance with all regulations applicable. In this case the internal auditor or SPI no longer only focuses on financial statements, but also provides an assessment of management operations so that they do not run out of control and in accordance with the objectives of an entity $[4,8]$.

Table 15. Coefficients

\begin{tabular}{ccccccc}
\hline \multirow{2}{*}{ Model } & \multicolumn{2}{c}{$\begin{array}{c}\text { Unstandardized } \\
\text { Coefficients }\end{array}$} & $\begin{array}{c}\text { Standardized } \\
\text { Coefficients }\end{array}$ & t & Sig. \\
\cline { 2 - 4 } & $\mathrm{B}$ & Std. Error & Beta & & \\
\hline (Constant) & 20,625 & 7,653 & & 2,695 &, 011 \\
TOTAL_SPI &, 668 &, 083 &, 821 & & 8,013 &, 000 \\
\hline a. Dependent Variable: TOTAL_GUG & & &
\end{tabular}


Based on table 15 , the regression equation is obtained as follows:

Note:

$$
\mathrm{Y}=\mathbf{2 0 , 6 2 5}+\mathbf{0 , 6 6 8}+\varepsilon
$$

$\mathrm{Y}=$ Good University Governance

$\mathrm{X} 1=$ Role of Internal Supervisors

$\varepsilon \quad=$ Error

Explanation:

1. In the regression equation above shows a positive constant value of 20.625. If the role of the internal control unit is assumed to be non-existent or 0 , then Good University Governance will be a constant of 20.625 .

2. The coefficient regression of SPI has a positive value of 0.688 , indicating that every change in 1 internal control unit can increase the realization of good university governance by 0.688 . Positive coefficient means that there is a positive relationship between the role of SPI on good university governance, if the role of SPI is getting better, the application of good university governance will increase and run better.

Based on the results of the $\mathrm{F}$ statistical test, the role of the internal control unit influences Good University Governance. The results of this study are in line with the results of research conducted by Untari $[3,9,10]$ whereas the role of the internal control unit significantly influences good university governance. Internal auditors or SPI are considered important in carry out its role to govern university and able to prevent fraud occurred so it can carry out its knowledge transfer functions optimally, to be accountable in financial management and in compliance with all regulations applicable. In this case the internal auditor or SPI not only focuses on the financial statements, but also provides an assessment of management operations so that they do not run out of control and in accordance with the objectives of the university.

\section{Recommendation}

1) Future research is expected to be able to add other independent variables, both from external factors and internal auditor factors or add moderating variables to find out other variables that can influence and strengthen or weaken the dependent variable. So that the results of the study better describe the effects of the actual dependent variable.

2) Future studies are expected to be able to add to the research sample and expand the research sample area, not only in the Medan Region but also in other regions, so that research results can be obtained with a higher level of generalization.

3) Future studies are expected to use different research methods such as the method of direct interviews with respondents to obtain higher quality data.

\section{References}

[1] Wijatno, s (2009). Pengelolaan Perguruan Tinggi Secara Efisien, Efektif dan Ekonomis untuk Meningkatkan Mutu Penyelenggaraan Pendidikan dan Mutu Lulusan. Jakarta: Salemba Empat..

[2] Ghozali, Imam.(2013), Aplikasi Analisis Multivariate dengan Program IBM SPSS 21 Update PLS Regresi. Semarang: Badan Penerbit Universitas Diponegoro. 
[3] Untari. (2015). Peran Satuan Pengawasan Intern (Spi) Dan Penerapan Internal Control Terhadap Pencapaian Good University Governance (Gug). Universitas Islam Negeri Syarif Hidayatullah. Jakarta.

[4] Agoes, Sukrisno. (2008). Auditing (Pemeriksaan Akuntan) Untuk Kantor Akuntan PublikEdisi Ketiga. Jakarta: FE UI.

[5] Amilin (2014), Laboratorium Auditing, Edisi kedua, Universitas Terbuka, Banten.

[6] Mulyadi, (2002), Buku 2 Auditing, edisi 6, Jakarta : Salemba empat.

[7] Pusat Pembinaan Profesi Keuangan, (2018), Buku Panduan ATLAS , IAPI, Jakarta.

[8] Rick Hayes et all (2017), Prinsip-prinsip pengauditan, Edisi 3, Jakarta : Salemba Empat.

[9] Wardah,Nurul (2015). Pengaruh Peran dan Kinerja Auditor Internal Terhadap Efektivitas Sistem Pengendalian Internal (Studi Empiris Perguruan Tinggi Badan Layanan Umum di Wilayah Provinsi Dki Jakarta dan Banten)

[10] Williem F Messier. (2014),,Jasa Audit dan Assurance, $8^{\text {th }}-E d$, Jakarta : Salemba Empat. 